\title{
Education of Religious Characters in Indonesia
}

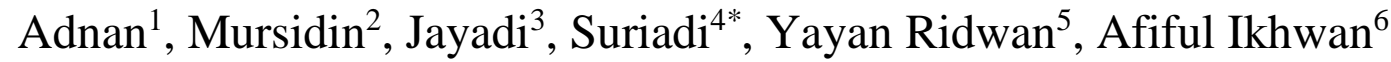 \\ 1,2,3,4,5 Institut Agama Islam Sultan Muhammad Syafiuddin Sambas, West Kalimantan, Indonesia \\ ${ }^{6}$ Universitas Muhammadiyah Ponorogo, East Java, Indonesia \\ Corresponding author. Email: ayualiyanda@gmail.com
}

\begin{abstract}
This article reviews about religious education in the congregation tariqah qadiriyah wa naqsyabandiyah. This research was conducted at the congregation in Sambas West Kalimantan. This research uses a qualitative approach with a method of data collection with interview techniques. The problem faced by nations in the world and Indonesia, in particular, is now being transformed by the need to globalize. This indicates that globalization is a phenomenon that cannot be avoided by anyone and any country. The consequences of globalization bring rapid changes and affect every aspect of life, including changes in moral values and social life. To overcome these problems, there is an immediate need to become a spiritual gate in internalizing religious values in living in the community.
\end{abstract}

\section{Keywords: Education, Thariqah, Religious Characters and Indonesia}

\section{INTRODUCTION}

The current process of globalization has added to all the nature of human life; its influence is very complex and significant. To fortify ourselves from influencing globalization, every human being understands its potential both physically and spiritually (Suriadi, 2017). The problem in community life, such as the gap between worldly and nuclear values, is expected. In such a situation, North Sumatra is a vehicle of choice for overcoming problems as described above. Modern, social human beings tend to promote reason (ratio) without paying attention to potential potency (qalb), whereas Islam does not make such dichotomy. This is important because when the mind is no longer able to solve problems, it is likely that it will be easy to get discouraged, depressed, stressed, and even commit suicide (Mufron et al., 2021). To deal with the various issues well, calm and patience are needed. Sufism as a discipline of Islamic sciences is a bargain for providing a balance between mind and heart functions. The concept that exists in Sufism teaches truly, diligently worshipping, and makes it easy to feel the beauty of life and the pleasure of worship (Siroj, 2006). If every citizen of the country genuinely implements the concept, it can likely improve towards a better spiritual and spiritual condition of the citizens. The institution is an institution that teaches tasawuf studies, practices the contents contained therein which are accompanied by mentors who have a philosophy to Apostle Muhammad PBUH Shortly, someone will learn everything about nufas (Syarifudin et al., 2020); (Ikhwan et al., 2020). Studies that have been studied in the world of North Sumatra are studies that are considered in the near universe. So, now it is not wrong to conclude that North Sumatra has become a tarekat (Sukardi, 2000). This congregation is one of the solutions in overcoming moral decadence that is happening now. The tarekat (sufism followers group) which in its initials is only 
intended as a method, method, and path taken by a Sufi to attain the highest spiritual, selfpurification or soul, to overcome the various problems of the nation today, namely moral decadence (Riyadi, 2014).

The facts above are not without reason, the data in the field prove this, based on the results of a study, for example, which was published by the Mind of the People Daily dated March 24, 2007, as quoted by Istavida, of 2,488 teenagers in Tasikmalaya, Cirebon, Singkawang, Sambas, and Kupang strengthens this. About $60 \%$ of them have sex (adultery) at the age of 18 years. Another study (2005) also mentions that the average age for sex is 18 years old, even $16 \%$ of them are $13-15$ years old, $85 \%$ of these are done at home with pimps. Then a similar action was taken against a Sambas State Middle School student, and it was found that the perpetrators were five men under the age of February 19 2018. More shockingly, based on the results of a study of the Interest of Demographics Indonesia in West Kalimantan, accounting for $57.1 \%$ of 70 prospective brides who are pregnant women are not wanted (pregnant out of wedlock) in Pemangkat District (not to mention various other cases (Data Pengadilan Agama Kabupaten Sambas, 2018).

\subsection{Overview Thariqah Qadiriyah wa Naqsyabandiyah}

The Founder of the Congregation of the Nahdlatul wa Naqsyabandiyah was Syaikh Ahmad Khatib Sambas born in Sambas West Kalimantan in 1217 H/ 1802 M. After completing religious education on a fundamental level in Sambas, he went to Mecca at the age of 19 to continue his studies and remained in the second quarter of the ninth century twelve, until his death in 1289 H / 1872 M (Jabbar, 1982). Various tasks learned to include a variety of Islamic knowledge, including North Sumatra, which has spiritual achievements that make them respectful of their time, and very influential throughout Indonesia (Yusuf, 2020). Among his, the teacher was Syaikh Daud ibn Abdullah ibn Idris al-Fatani (d. 1843), a professor who had also lived in Makkah, Syaikh Syamsudin, Syaikh Muhammad Nrsyad al-Banjari (d. 1812), and Syaikh Abd. Al-Shamad alPalimbani (d.1800). Of all Syaikhs Shamsuddin's students, Syaikh Ahmad Khatib Sambas reached the highest level of perfection and authority and was designated as mursyid Kamil Mukammil. The development of the same as naqsabandiyah (qadiriyah) was for the efforts of a Sheikh named Ahmad Khatib Sambasi. From them, the near qadiriyah naqsabandiyah began to spread its influence throughout the archipelago (Muhayat, 2019). Snouck also ensured that among the pilgrims who settled in Mecca at that time, they placed the tarekat (specifically naqsabandiyah or qadiriyah naqsabandiyah) in the highest position in the religious sciences they studied. This is a question of why they are more interested in being compared to other religious sciences (Iqbal, 2016).

\subsection{Religious Character}

Words of English characters character, Greek language, namely harassing, which means to engrave (Ryan, 1999). The word to stamp can be translated carving, painting, making in, engraving or scratching. While the understanding of character according to the Ministry of Education's Language Center is narration, heart, soul, personality, mind and character, behaviour, personality, character, character (Susanti, 2016). Temperament, character (Suriadi Samsuri, Mursidin, 2018). The style is personality, behaviour, attitude, integrity, and nature. In Arabic, the figure is interpreted as khuluq, sajiyyah, thabu'u (morality, character, character), often interpreted as syakhshiyyah, 
which means more to personality (personality). (Boang, 2011) In this way, people with nature say, people who are personable, behave, characteristically, or characteristically (Fery Diantoro, 2018). Minimologically, the meaning of character found by Thomas Nickona means a most profound role that can be relied upon to respond to situations ethically and morally.

Furthermore, Lickona adds that $\mathrm{n}$ characters are arranged in three interrelated parts, namely knowledge about immorality, moral feeling, and ethical behaviour (Lickona, 1991); (Ikhwan, 2016). From the definition of the above character, it can be understood that the style is identical to the role so that character is universal values of human behaviour which encompass all human activity both in terms of relationships with God, self, human likeness and environment that manifests in thoughts, attitudes, feelings, statement, and its implementation based on religious norms, law, manners, culture, and traditional customs (Ikhwan, 2017).

Religious originates from the word religious, which means the spiritual nature inherent in someone (Gazalba, 1985). Moral value is a form of human relations with its creators through religious nagas that have been internalized in a person and reflected in their daily attitudes and behaviour (Rohmad et al., 2020)-sacred as one of the character values described as respectful attitudes and behaviours in carrying out religious teachings, being tolerant of other spiritual practices, and living in harmony with other religious adherents (Wahyudi, 2018); (Kemendiknas, 2010). Specifically, character education based on ethical values refers to the fundamental values contained in religion (Islam) (Kusno, Joko Purwanto, 2004). Religious character is a characteristic that is attached to a person or entity that shows identity, integrity, compliance or Islamic message (Prima Veronika, Budhi Setiawan, 2017).

According to Nurcholish Madjid, the religious character is not just a prayer and reading the prayer. Still, more than that, namely the whole of human behaviour that is commendable, carried out to obtain the blessings of Allah SWT. In line with Ngainum Naim interpreting religious character is the whole of human behaviour that is praiseworthy, carried out by someone who is non-Muslim as a caliph in the face of the earth for the pleasure of Allah SWT (Naim, 2012). This is like the Word of Allah SWT contained in QS. al-Baqarah (2) verse 208: "O you who believe, enter into the whole of Islam, and do not follow the steps of evil". Indeed, the shaitan is a real enemy to you. From some of the explanations above, it can be understood that religious character is the values of life that reflect the growth of spiritual experience which consists of three main elements, namely aqidah, ibadah and the traits that guide behaviour according to rules or to reach prosperity and the happiness of life in the world and the hereafter.

\section{METHOD}

This study uses the approach of qualitative research with the design of case studies. The reason for using the qualitative approach because in this study deepens the main focus, namely the education of religious characters in the Jama'at Tariqah Naqsyabandiyah nativity in the Sambas Regency. This is a process, event or activities of a person (some people) to process operations in instilling religious values, which must reveal truth and truthfulness in research, so that observations that are rooted in nature are needed to understand social phenomena or symptoms comprehensively and contextual by describing the empirical reality of object being researched. Research that is based on observation and interview 
does not mean that it can't be said to be qualitative because the task of qualitative researchers is also to interpret the beliefs and behaviours of the participants. Referring to the above opinion, the primary data obtained will be analyzed according to the interactive model following the instructions of Miles \& Huberman, namely (1) data reduction, (2) data presentation and (3) conclusions (temporary conclusions, verification and conclusions) (B. M. Matthew and $\mathrm{H}$. A.Michael, 1994).

\section{RESULT AND DISCUSSION}

Character values that have been instilled in the Thariqah congregation in the Nahdlatul Naqsyabandiyah are the values of education that are based on Islamic teachings. Character values carried out by guidance by a murshid or teacher. Character values in the instructions of the thariqah of the naqsabandiyah nativity are $\mathrm{n}$ values of education originating from the teachings of Islam. The benefits of characters that are instilled in worshipers include: first, religious values. Religious values are attitudes and behaviours to understand, appreciate and practice spiritual teachings with moral importance as daily life guidelines (Ikhwan et al., 2019). This can be seen when jama'ah (society), together with mursyid, read basmallah and al-fatihah before the study was conducted. This can also be proven when they enjoy the routine during the Islamic research and study process because they are motivated to get closer to Allah, according to the words of the Prophet. Second, the value of the honest character is values that are manifested by trying to make someone trustworthy in words, actions, and work. This can be seen from every job given by the teacher to be done alone. Even so, some honestly admit that friends assist their duties because time is up. Apart from that, honesty can be seen when a teacher loses his trumpet when he teaches in the class and then there is an employee who claims to have found it. Rasulullah SAW. Said, "Verily, honesty shows the virtues and virtues that show to heaven. Someone always acts honestly until it is determined for him to be honest" (H. R. Bukhari). The three values of character are humble. The role of humility is the nature of someone who cares deeply about the feelings of others and has never lowered anyone. When they want to start the lesson they reveal expressions of humility; fourth, the value of the character of respect for knowledge, respect for education is a behaviour that recognizes that expertise must be sought and sought with the maximum and maximum amount, the value of respect and courtesy. The character of respect and courtesy is a behaviour that places a person who is older or smarter to be respected and to get politeness behaviour as he respects and behaves politely to his people. al-Abrasyi: Stand up and respect the teacher and give appreciation; the teacher is almost an Apostle."

\section{CONCLUSION}

From the results of this study, it is always the way of referring to the medical and formal systems, which is a clue in carrying out worship by the teachings exemplified by the Prophet to the teachers who connect continuously without interruption. The qodiriyah Congregation naqsabandiyah is a combination of two congregations, namely the approach of qodiriyah and naqsabandiyah so that it becomes a new approach, founded by an Indonesian Sufi who is named Syaikh Ahmad Khatib Sambas. This universal teaching generally has five main points: First, studying science related to the implementation of all commands, second; accompanying teachers and friends as close as possible to see how to do a service, third; 
n leaving all rukhah and $t a$ 'wìl to guard and maintain charity perfection, fourth; keep and use time and fill it with all wirid and $d o^{\prime} a$ to strengthen khusyu' and $\underline{h \bar{u} d u r}$, and fifth; curb yourself not to get out of lust and keep yourself awake.

\section{REFERENCES}

[1] B. M. Matthew and H. A.Michael. (1994). Qualitativeh Datah Analysish:," in A Sourceh Bookh of New Methodes. C.A.Sage.

[2] Boang, A. (2011). Mozaik Pemikiran Islam: Bunga Serampai Pemikiran Pendidikan Indonesia. Dirjen Dikti.

[3] Data Pengadilan Agama Kabupaten Sambas. (2018).

[4] Fery Diantoro. (2018). Positioning Madrasah Dalam Penguatan Pendidikan Karakter (Perspektif Peraturan Presiden No. 87 Tahun 2017 Tentang Penguatan Pendidikan Karakter). Al-Hayat: Journal of Islamic Education, 02(01), 1-23.

[5] Gazalba, S. (1985). Asas Agama Islam. Bulan Bintang.

[6] Ikhwan, A. (2016). Manajemen pengembangan kurikulum Keaswajaan dan Kemuhammadiyahan dalam Pembentukan karakter: Studi Multikasus di Sekolah Tinggi Agama Islam Diponegoro dan Sekolah Tinggi Agama Islam Muhammadiyah Tulungagung [Universitas Islam Negeri Maulana Malik Ibrahim Malang]. http://etheses.uinmalang.ac.id/9992/

[7] Ikhwan, A. (2017). Development Of Quality Management Islamic Education In Islamic Boarding School (Case Study Madrasah Aliyah Ash Sholihin). Al-Hayat: Journal of Islamic Education, 1(1), 117. http://alhayat.or.id/index.php/alhayat/ article/view/7

[8] Ikhwan, A., Aderi Che Noh, M., \& Iman, N. (2020). Implementation of The Tahfidz al-Qur'an Curriculum at the Tahfidz Malaysia Boarding School. Journal of Critical Reviews, 7(8), 866-870.

[9] Ikhwan, A., Biantoro, O. F., \& Rohmad, A. (2019). The Role of the Family in Internalizing Islamic Values. Dinamika Ilmu, 19(2), 323. https://doi.org/10.21093/di.v19i2.174 6

[10] Iqbal, M. (2016). Tarekat Naqsabandiyah di Indonesia Abad 19 dari Ortodoksi ke Politisas. Jurnal Intizar, 22(2).

[11] Jabbar, U. A. (1982). Siyar wa Tarajim ba"du: Ulama"ina fi al-AlQarn al-Rabi. tihama.

[12] Kemendiknas. (2010). Pengembangan Pendidikan Budaya Dan Karakter Bangsa: Pedoman Sekolah. Balitban.

[13] Kusno, Joko Purwanto, M. (2004). Model Pendidikan Karakter Religius Berbasis Pada Pengetahuan Matematika Sekolah. Jurnal Nasional Universitas Muhammadiyah Purwokerto.

[14] Lickona, T. (1991). Educating for Character: How Our School Can Teach Respect and Responsibility. Bantam Books.

[15] Mufron, A., Ikhwan, A., Syuhada, M., \& Ridlowi, A. (2021). Optimizing the Organizational Structure in Transforming Human Resources Who Can Manage Work Stress With a Religious Culture. 08(03), 11101126.

[16] Muhayat, I. (2019). Development of Teacher Position in Islamic Education Institutions: Teachers as Professional Educators. Istawa: Jurnal Pendidikan 
Islam, 4(1), 1-14. https://doi.org/10.24269/ijpi.v4i1.164 0

[17] Naim, N. (2012). Character Building. Ar-Ruzz Media.

[18] Prima Veronika, Budhi Setiawan, N. E. W. (2017). Implementasi Pembelajaran Bahasa Jawa (Materi Tembang Dolanan) Berbasis Pendidikan Karakter Religius Dalam Kurikulum 2013. Jurnal El-Harakah, 19(1).

[19] Riyadi, A. (2014). Tarekat Sebagai Organisasi Tasawuf (Melacak Peran Tarekat Dalam Perkembangan Dakwah Islamiyah). Jurnal AtTaqaddum, 6(2).

[20] Rohmad, A., Ikhwan, A., \& Tumin, T. (2020). Strengthening the competency of lecturers of state Islamic religious college in Indonesia. International Journal of Advanced Science and Technology, 29(4), 1653-1663.

http://sersc.org/journals/index.php/IJ AST/article/view/7275

[21] Ryan, K. (1999). Building Character in Schools: Practical Ways to Bring Moral Instruction to Life. Jossey Bass.

[22] Siroj, S. A. (2006). Tasawuf Sebagai Kritik Sosial. Mizan Pustaka.

[23] Sukardi. (2000). Kuliah-kuliah Tasawuf. Pustaka Hidayaha.

[24] Suriadi. (2017). Pendidikan Sufistik Tarekat Qadiriyyah Wa Naqsyabandiyyah (Kajian Atas Pemikiran Ahmad Khatib Sambas).
Jurnal Khazanah, 15(2).

[25] Suriadi Samsuri, Mursidin, M. (2018). Character Education Based on Gender Justice in The Islamic Perspective. Al-Hayat: Journal of Islamic Education, 2(2), 202-212. http://alhayat.or.id/index.php/alhayat/ article/view/26

[26] Susanti, S. (2016). MEMBANGUN PERADABAN BANGSA DENGAN PENDIDIKAN KARAKTER. Istawa: Jurnal Pendidikan Islam, 1(2), 139159.

https://doi.org/10.24269/ijpi.v1i2.173

[27] Syarifudin, f. A., Ikhwan, A., Tantowi, A., Hubur, A. A., \& Susilawati, S. (2020). Determinant factor of personality changes in education. Journal of Critical Reviews, 7(17), 518-524. https://doi.org/10.31838/jcr.07.17.72

[28] Wahyudi, A. (2018). Character Education Development Pattern: Efforts to Empower School Managers. Al-Hayat: Journal of Islamic Education, 3(2), 262-270. https://doi.org/https://doi.org/10.3572 3/ajie.v2i2.41

[29] Yusuf, S. M. (2020). Intersubjectivity of khalwat (suluk) members in the tarekat Naqsyabandiyah Khalidiyah Ponorogo. Indonesian Journal of Islam and Muslim Societies, 10(1), 103-126.

https://doi.org/10.18326/ijims.v10i1.1 03-126 